\title{
Evaluation of the use of library resources and services in Higher Education
}

\section{Evaluación del uso de los recursos y servicios bibliotecarios en Educación Superior}

\author{
OCHOA-ALCÁNTAR, José Manuel†*, ALDRETE-CASTELO, Juan Carlos, RIVERA-IRIBARREN, \\ Maricel and GARCÍA-LÓPEZ, Ramona Imelda
}

\author{
Instituto Tecnológico de Sonora, México
}

ID $1^{\text {st }}$ Author: José Manuel, Ochoa-Alcántar / ORC ID 0000-0003-1202-6833, Researcher ID ABH-3071-2021, CVU CONACYT ID 92857

ID $1^{\text {st }}$ Co-author: Juan Carlos, Aldrete-Castelo / ORC ID 0000-0002-9622-808X, Researcher ID ABH-3073-2021, CVU CONACYT ID 1174219

ID $2^{\text {nd }}$ Co-author: Maricel, Rivera-Iribarren / ORC ID 0000-0003-1823-0149, Researcher ID S-7893-2018, CVU CONACYT ID: 896629

ID $3^{\text {rd }}$ Co-author: Ramona Imelda, García-López / ORC ID 0000-0003-0091-3427, Researcher ID P-1363-2014, CVU CONACYT ID 257894

DOI: $10.35429 /$ JET.2021.14.5.21.29

Received March 14, 2021; Accepted June 30, 2021

\begin{abstract}
In order to evaluate the use of library resources and services by the students of the Technological Institute of Sonora and determine their level of general satisfaction with library services, a quantitative investigation was carried out, with a non-experimental design, transversal type and with a descriptive scope. The population was made up of undergraduate $(\mathrm{N}=17,532)$, master's $(\mathrm{N}=$ 414) and doctorate $(\mathrm{N}=72)$ students, a total of 18,818 students enrolled in August 2019 in the Obregón, Navojoa and Guaymas Academic Units of said university. The instrument used was designed for this perception assessment exercise, which consists of 25 multiple-choice and 1 open-ended questions. A total of 1,454 valid responses were obtained that averaged a satisfaction level of 4.00 points, which means that users are "satisfied" with the services received in the evaluated cycle. It is recommended that these numerical indicators be used to increase satisfaction in the areas that were well evaluated, but, on the other hand, corrective actions should be taken in those services whose mean has been the lowest.
\end{abstract}

University libraries, Evaluation, Quality

\begin{abstract}
Resumen
Con el objetivo de evaluar el uso de los recursos y servicios bibliotecarios por parte de los estudiantes del Instituto Tecnológico de Sonora y determinar su nivel de satisfacción general con los servicios bibliotecarios, se llevó a cabo una investigación cuantitativa, con un diseño no experimental, de tipo transversal y con un alcance descriptivo. La población se conformó por estudiantes de pregrado $(\mathrm{N}=17,532)$, maestría $(\mathrm{N}=414)$ y doctorado $(\mathrm{N}=72)$ siendo un total de 18,818 estudiantes inscritos en agosto de 2019 en las Unidades Académicas Obregón, Navojoa y Guaymas de dicha universidad. El instrumento utilizado fue realizado para este ejercicio de evaluación de la percepción, el cual consta de 25 preguntas de opción múltiple y 1 de respuesta abierta. Se obtuvo un total de 1,454 respuestas válidas que promediaron un nivel de satisfacción de 4.00 puntos, lo cual significa que los usarios se encuentran "satisfechos" con los servicios recibidos en el ciclo evaluado. Se recomienda que estos indicadores numéricos sean usados para el aumento de la satisfacción en las áreas que salieron bien evaluados, pero, por otro lado, deben realizarse acciones correctivas en aquellos servicios cuya media haya sido la más baja.
\end{abstract}

Bibliotecas universitarias, Evaluación, Calidad

Citation: OCHOA-ALCÁNTAR, José Manuel, ALDRETE-CASTELO, Juan Carlos, RIVERA-IRIBARREN, Maricel and GARCÍA-LÓPEZ, Ramona Imelda. Evaluation of the use of library resources and services in Higher Education. Journal Educational Theory. 2021. 5-14: 21-29

\footnotetext{
* Correspondence to Author (e-mail: jose.ochoa@itson.edu.mx)

$\dagger$ Researcher contributing as first author.
} 


\section{Introduction}

The purpose of university libraries is to support the academic programs of a university by providing relevant information to respond to the information demands of users, that is, students and academic staff. The 21st century poses radical challenges to university libraries, as their functions and services are influenced by issues that affect the way services are provided in a library on a regular basis (Opoku, 2011).

These challenges require that the evaluation of university library services continue to be valuable as it represents the surest way to ensure that information is obtained to determine whether the expected objectives are being met and that the necessary adjustments are made for the effective provision of library services. information services. In line with this, the purpose of evaluation (of a library), according to Knighty (cited in Emokiniovo, 2012) is to collect information on how its objectives are being achieved with the intention of improving the provision of services.

\section{Background}

Academic libraries are an integral part of an institution of higher education or a research center (Reitz, 2004), and are managed to meet the information and research needs of its students, faculty, and administrative staff. The university library is defined as "a library or a library system established, managed and funded by a university to meet the information, research and curriculum needs of its students, faculty and staff” (Reitz, 2004).

Aina (2005) affirms that the purpose of a university library is to support the objectives of a university, specifically the areas of learning, teaching, research and service. Ekere (2006) also shares this point of view by stating that the main purpose of the university library is to support the objectives of the university by promoting teaching, learning and research. Thus, the university library is intended to serve undergraduate (undergraduate), graduate students, professors and other members of the university community.
As a result, libraries in higher education institutions are often considered the most important resource center of an academic institution. Roseroka (2004) considers that university libraries derive their mission from the university; that vision, mission and strategies that are selected by universities as a guide to fulfill the central functions of teaching, learning, research and the provision of community services. Okunu, Akalumhe and Monu (2011) conclude that the university library is the heart of the university.

However, university education in Mexico faces a critical challenge in meeting the new demands of the 21 st century, with everincreasing population growth, inadequate library facilities, resources, and insufficient funding (CONPAB, 2015). Opoku (2011) also perceived this when he stated that: "the academic library service is a complex and dynamic collaboration between the library staff and the user. Many problems affect the way library services are delivered on a regular basis.

The increasing influx of students into the university, together with the advanced development of information and communication technologies (ICT) every day, has created a new type of library users demanding more efficient library services. If checks and balances are put in place, and the components of the library are managed efficiently and effectively, the library is likely to meet the expectations of users in the provision of its services.

Therefore, it is necessary for academic libraries to promote and provide quality information services that meet the needs of students and teachers and motivate them to make more use of library services. The library needs to continually optimize the interactions of all its components to ensure that the changing goals of the library are met and to improve both user interaction and relationship over time "(p. 198).

Therefore, considering these challenges, the evaluation of the use of libraries by students and staff in the universities of Mexico is an important exercise that must be carried out frequently, systematically and correctly planned, because some factors influence the how library services are delivered and in the use of library students and staff. 
Emokiniovo and Ogunrobi (2012) mention that evaluation (of a library) is the process by which information about its perceived use by students is systematically collected and analyzed through the use of evidence (tests), numerical values for evidence (measurement) and the use of the results to make decisions (evaluation). The purpose of the evaluation is to collect information on how the library is achieving its objectives with a view to improving the provision of its essential services (Knightyas, cited by Emokiniov and Ogunrobi, 2012).

\section{Objective}

The main objective of this study is to evaluate the use of library resources and services by undergraduate and graduate students of the Technological Institute of Sonora (ITSON) in its 4 academic units that comprise the library system with 5 buildings in Ciudad Obregón ( Náinari and Centro Libraries), Guaymas, Empalme, and Navojoa:

- Determine the general level of user satisfaction with library services.

- Determine the user's particular level of satisfaction with library services

- Determine if there is a difference in satisfaction between libraries.

\section{Research questions}

The following research questions were posed to guide this study:

1. To what extent are students satisfied with the services and facilities provided?

2. To what extent are students satisfied with the services and facilities provided in a particular way?

3. Is there a difference in the level of satisfaction that depends on the particular service of any of the 5 libraries?

\section{Type of study}

The present investigation is a study of a quantitative methodological nature, with a nonexperimental design, of a cross-sectional (or transectional) type and with a descriptive scope. It is quantitative because magnitudes or occurrences of the phenomenon were estimated; not experimental because variables were not deliberately manipulated.
Cross-sectional because the data were collected in a single moment; descriptive because its objective was to specify the nature of a demographic segment, without focusing on the reasons why a certain phenomenon occurs, that is, the research topic is described, without covering why it occurs (Gall et al., 2007; Hernández-Sampieri and Mendoza-Torres, 2018; Kerlinger and Lee, 2002).

\section{Participants}

The population is made up of undergraduate $(\mathrm{N}$ $=17,532)$, master's $(\mathrm{N}=414)$ and doctorate $(\mathrm{N}$ $=72$ ) students that make up a total of 18,818 students enrolled in August 2019 in the Obregón, Navojoa and Guaymas Academic Units of the Institute Tecnológico de Sonora, in the state of Sonora, Mexico (see Table 1).

\begin{tabular}{|c|c|c|c|c|}
\hline Unit & $\begin{array}{c}\text { Bachelor's } \\
\text { degree }\end{array}$ & $\begin{array}{l}\text { master's } \\
\text { degree }\end{array}$ & $\begin{array}{c}\text { Doctorat } \\
\text { e }\end{array}$ & Total \\
\hline Obregon & 12,502 & 330 & 72 & 12,904 \\
\hline Navojoa & 2,566 & 49 & 0 & 2,615 \\
\hline $\begin{array}{l}\text { Guaymas } \\
- \\
\text { Empalme }\end{array}$ & 2,464 & 35 & 0 & 2,499 \\
\hline Total & 17,532 & 414 & 72 & 18,018 \\
\hline
\end{tabular}

Table 1 Total enrollment in the August 2019 cycle, by Academic Unit and by academic level.

Source: Self Made

\section{Sample}

The type of sample that was used was nonprobabilistic or directed by quotas, the sample size being 377 students, even so the instrument was distributed to the total population and the valid responses obtained were 1,457 , which represents $8 \%$. of the total enrollment of the university in the aforementioned school year (see Figure 1).

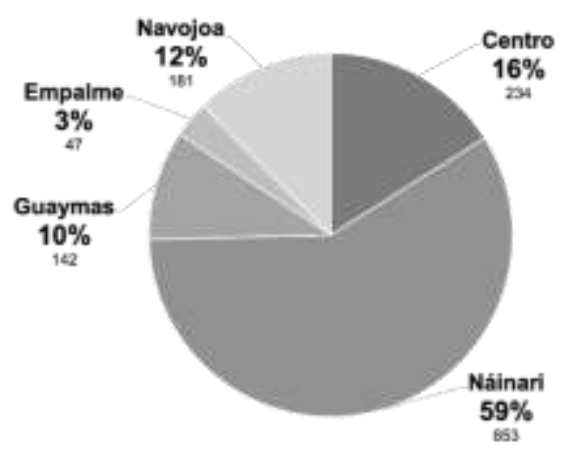

Figure 1 Total participants per unit and affiliation campus Source: Self Made 


\section{Instruments}

The instrument used was carried out for this perception assessment exercise, which consists of 25 multiple-choice questions and 1 openended question:

- Demographic or identification questions: 2.

- $\quad$ Reasons for attending the library: 1.

- Evaluation of satisfaction with the library: 20.

- $\quad$ Library qualification summary: 1.

- $\quad$ ITSON qualification summary: 1.

- Open question for additional comments: 1.

The survey was distributed electronically using the email of all students enrolled at the time, to whom the invitation to participate was sent, providing their response no later than December 18, 2019 and providing the appropriate information related to confidential treatment. of your personal data.

\section{Analysis of data}

For the data analysis, we first proceeded to the data capture and analysis in the SPSS statistical package; A description and summary of the variables was made using descriptive statistics (frequency tables, use of measures of central tendency and graphs).

\section{Results}

Once the information collection instrument was closed to student participation (on December 18 , 2019), the responses deposited there were downloaded and prepared to be transferred to the SPSS statistical package for processing.

The student body was asked about the main reasons why they attend the library, knowing in advance that they not only do it for the use of the physical collection, the most common answer (fashion) was to attend to study, followed by the performing teamwork and thirdly, performing work individually (see Figure 2).

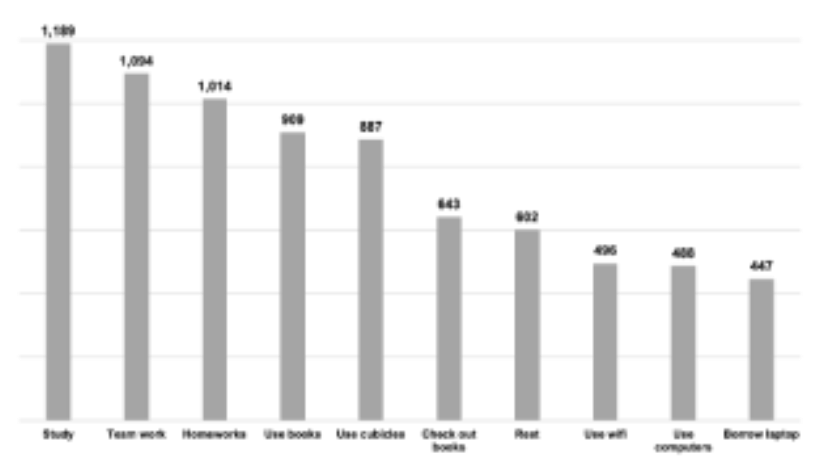

Figure 2 Reasons for attending the library. Source: Self Made

The next 20 questions were related to the level of satisfaction they present with respect to aspects that library staff consider crucial for their evaluation for immediate continuous improvement. The response scale that was used in all of them is the following, so the means will be expressed in a minimum of 1 point and a maximum of 5 points:

$$
\begin{array}{ll}
- & \text { Very dissatisfied }(\text { value }=1) \\
- & \text { Dissatisfied }(\text { value }=2) \\
- & \text { Undecided }(\text { value }=3) \\
- & \text { Satisfied }(\text { value }=4) \\
- & \text { Very satisfied }(\text { value }=5)
\end{array}
$$

The question related to the hours refers to the opening and closing hours of the buildings, where the average satisfaction was 4.17 points, which according to the scale used is equivalent to "satisfied" (see Figure 3).

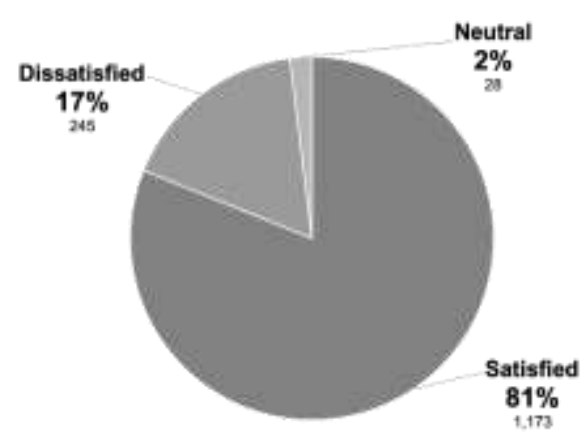

Figure 3 Level of satisfaction with the schedule Source: Self Made

Regarding the attention received by the staff of the various areas of the library (from the headquarters, coordination, reference, circulation), the students showed a level of satisfaction "satisfied" with an average of 4.04 points (see Figure 4). 


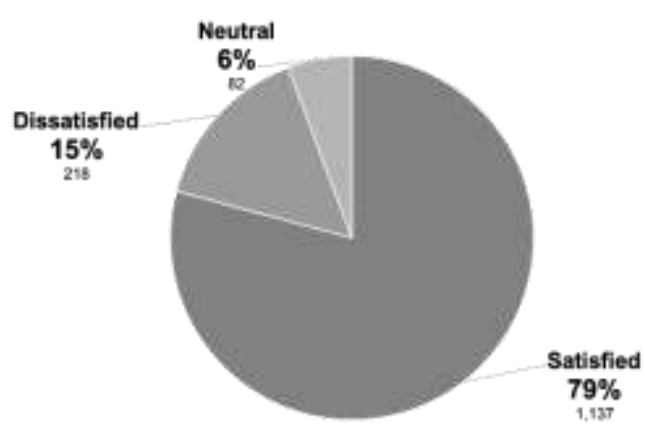

Figure 4 Level of satisfaction with the staff working in the library

Source: Self Made

The search catalog is the web tool that is made available to students as a browser, whose objective is to find the physical and digital heritage that is part of the library system. The average that the students gave to said system is 3.93 points, which is equivalent to satisfied (see Figure 5).

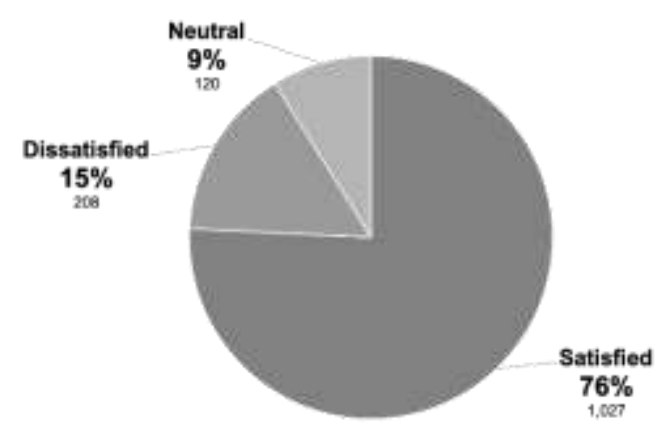

Figure 5 Level of satisfaction with the search catalog Source: Self Made

The availability of basic bibliography and reference books is one of the main functions of a library, so the next question measures your level of satisfaction with this element, as can be seen in Figure 6, the mean satisfaction was 3.95 points which means they are satisfied.

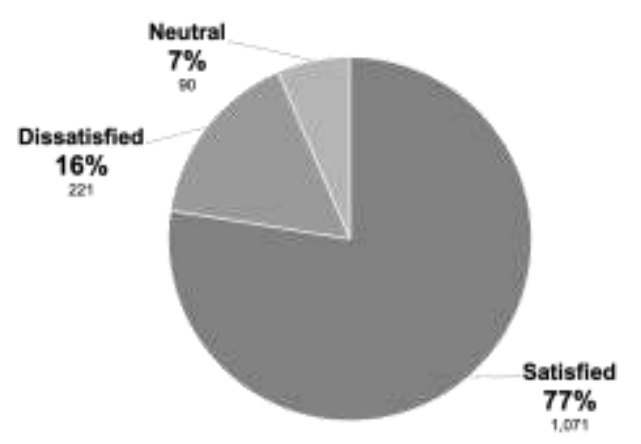

Figure 6 Level of satisfaction with the availability of books

Source: Self Made
Ease of finding books refers to the collection being easy to locate on the shelf, not being placed in the wrong place, and signage supporting the search. The mean obtained was 3.83 points (satisfied). See Figure 7.

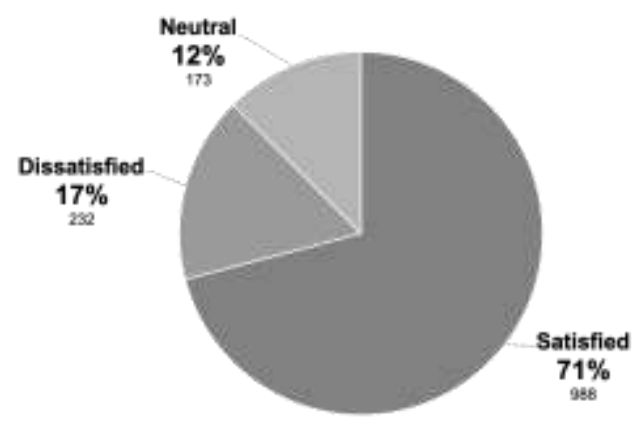

Figure 7 Level of satisfaction with the ease of finding books

Source: Self Made

The deadlines for students to return to the library all that collection that they have requested for their use at home, in addition to the amount of collection that they can take home, had lacked updating and consultation with the end user, so it was asked their opinion in this regard, obtaining an average of 3.96 points for the deadline to return the books to the library, and 4.00 for the number of books allowed to take home (satisfied). See Figures 8 and 9.

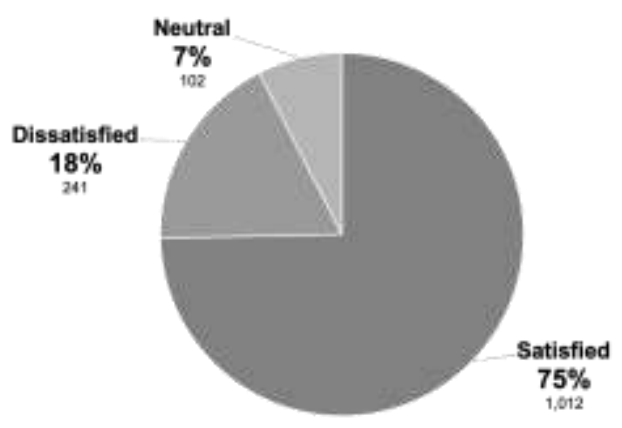

Figure 8 Level of satisfaction with the deadline for returning books

Source: Self Made

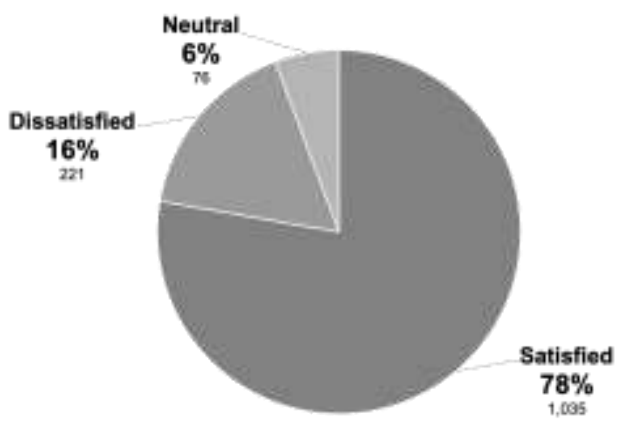

Figure 9 Level of satisfaction with the number of books allowed at home Source: Self Made

OCHOA-ALCÁNTAR, José Manuel, ALDRETE-CASTELO, Juan Carlos, RIVERA-IRIBARREN, Maricel and GARCÍA-LÓPEZ, Ramona Imelda. Evaluation of the use of library resources and services in Higher Education. Journal Educational Theory. 2021 
The physical cleaning of the building (general), but specifically of the bathrooms, was addressed in the following two questions (see Figures 10 and 11), in which an average of 4.27 points was obtained in general cleaning and 4.05 points in the cleanliness of the bathrooms, both satisfied.

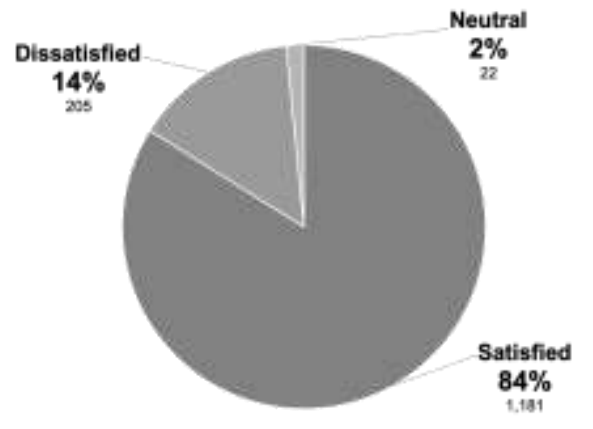

Figure 10 Level of satisfaction with the cleanliness of the building

Source: Self Made

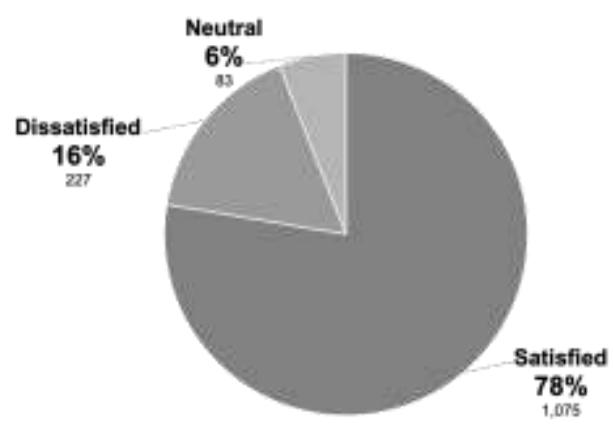

Figure 11 Level of satisfaction with the bathrooms Source: Self Made

The next question addressed their satisfaction with the furniture, specifically, tables, chairs and armchairs, for which an average of 4.19 points was obtained (satisfied). See Figure 12.

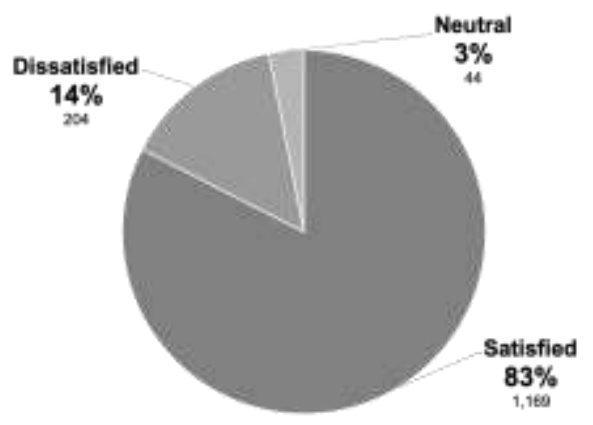

Figure 12 Level of satisfaction with the furniture. Source: Self Made

The cubicle loan is a service that is provided for the realization of teamwork and where conversations can be carried out with a moderate voice.
The average obtained was 4.10 points (satisfied). See Figure 13.

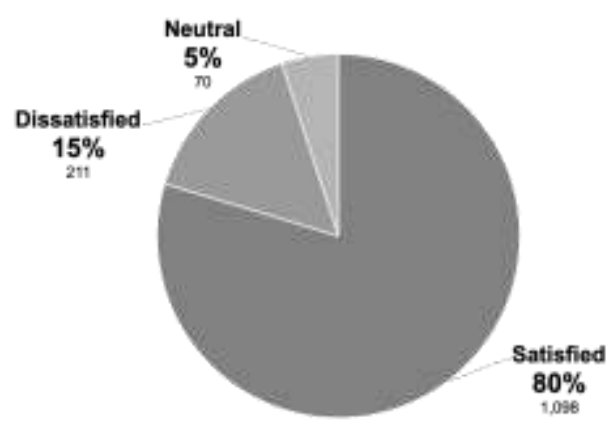

Figure 13 Level of satisfaction with the cubicles Source: Self Made

The technology services evaluated refer to the loan of laptops in the rooms, where an average of 3.78 points was obtained; laptops for internal use had an average of 3.94 points; wireless internet was rated with an average of 3.91 points; and the loan renewal web system with an average of 3.98 points. The 4 services were found to be "satisfied". See Figures 14, 15, 16 and 17.

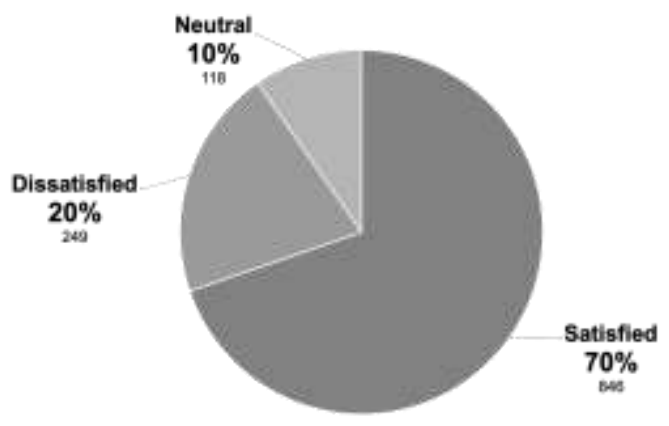

Figure 14 Level of satisfaction with the loaner laptops in the room

Source: Self Made

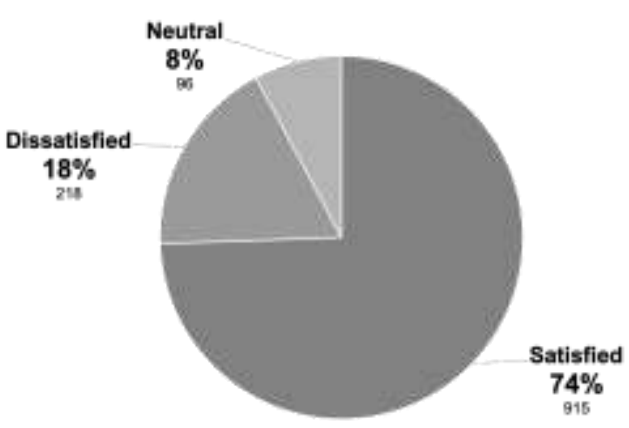

Figure 15 Level of satisfaction with desktop computers (computer room) Source: Self Made 


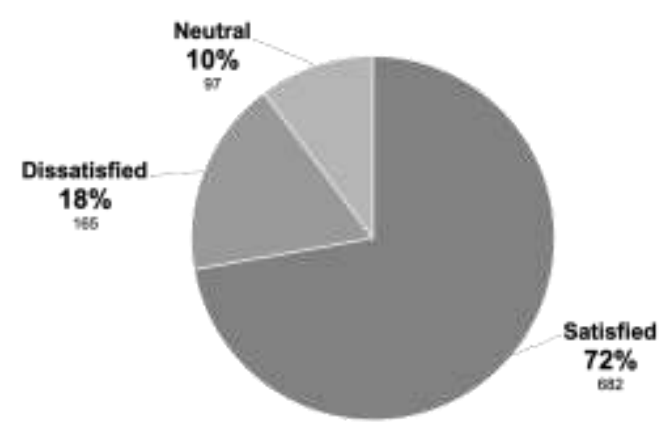

Figure 16 Satisfaction level with wireless internet Source: Self Made

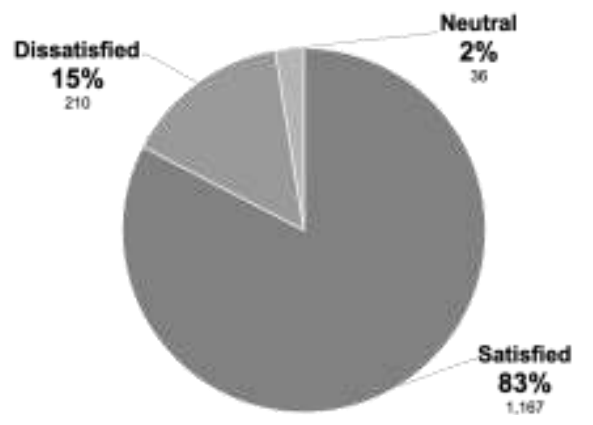

Figure 17 Level of satisfaction with the web renewal of home loans

Source: Self Made

The reference service was evaluated through the face-to-face courses that were offered during the August-December 2019 cycle in the different libraries, which received an average of 3.86 points, which is equivalent to "satisfied" on the scale used (see Figure 18 ).

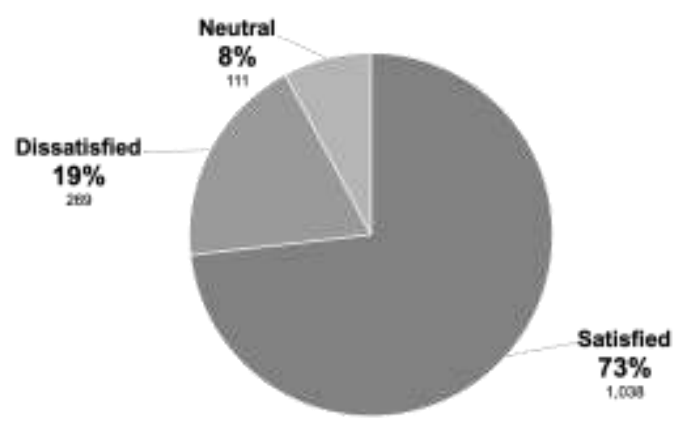

Figure 18 Level of satisfaction with the training courses of the reference service

Source: Self Made

The physical infrastructure was evaluated through the level of satisfaction with various aspects; the first of them was air conditioning (Figure 19) in which an average of 4.21 points was obtained; the noise level (Figure 20) with an average of 3.88 points; and the internal lighting of buildings (Figure 21) with an average of 4.20 points. The 3 indicators resulted in a level of "satisfied".

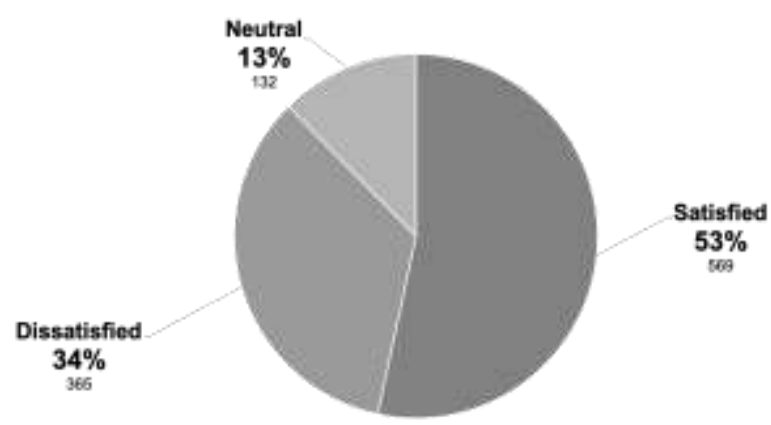

Figure 19 Satisfaction level with the air conditioning Source: Self Made

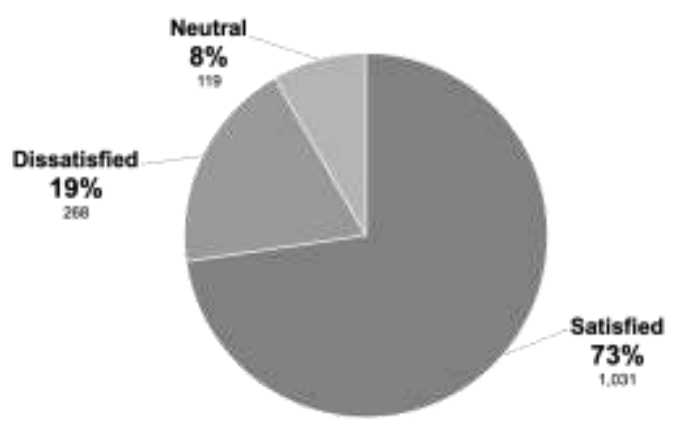

Figure 20 Level of satisfaction with noise. Source: Self Made

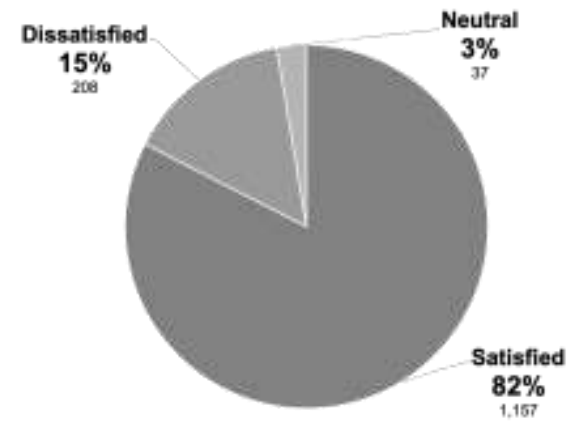

Figure 21 Level of satisfaction with the internal lighting of the building

Source: Self Made

Finally, the service of the copy center was evaluated, which is available in all libraries except the Navojoa Unit. This was the lowest indicator in the survey, as it obtained an average of 3.32 points, which is equivalent to the "undecided" level of satisfaction (see Figure 22).

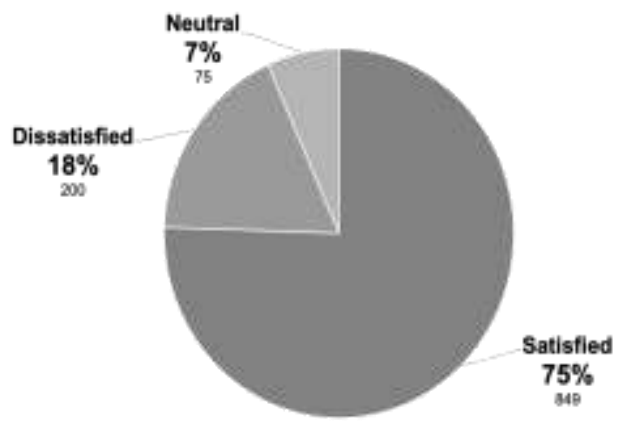

Figure 22 Level of satisfaction with the copy center Source: Self Made

OCHOA-ALCÁNTAR, José Manuel, ALDRETE-CASTELO, Juan Carlos, RIVERA-IRIBARREN, Maricel and GARCÍA-LÓPEZ, Ramona Imelda. Evaluation of the use of library resources and services in Higher Education. Journal Educational Theory. 2021 
As a summary, Table 2 is presented, where you can see the average obtained in each of the 20 questions of the evaluation questionnaire, being able to observe that the 5 best evaluated elements were cleanliness $(\mathrm{M}=$ 4.27), air conditioning $(M=4.21)$, lighting $(M=$ 4.20), furniture $(M=4.19)$ and opening and closing hours $(\mathrm{M}=4.17)$.

The 5 services with the lowest average in the evaluation were the copy center $(\mathrm{M}=3.32)$, the internal loan of laptops $(\mathrm{M}=3.78)$, the ease of finding books $(\mathrm{M}=3.83)$, the courses that were impart $(\mathrm{M}=3.86)$ and noise level $(\mathrm{M}=$ 3.88).

\begin{tabular}{|l|c|}
\hline \multicolumn{1}{|c|}{ Aspect to evaluate } & Average \\
\hline Cleaning & 4.27 \\
\hline Air conditioning & 4.21 \\
\hline illumination & 4.20 \\
\hline Furniture (tables, armchairs, chairs) & 4.19 \\
\hline Schedule & 4.17 \\
\hline Cubicles & 4.10 \\
\hline Toilets & 4.05 \\
\hline Library staff & 4.04 \\
\hline Number of books allowed at home & 4.00 \\
\hline Online loan renewal & 3.98 \\
\hline Deadline to return borrowed books at home & 3.96 \\
\hline Book availability & 3.95 \\
\hline Desktop computers & 3.94 \\
\hline Collection search catalog & 3.93 \\
\hline Wireless Internet & 3.91 \\
\hline Noise level & 3.88 \\
\hline Courses taught & 3.86 \\
\hline Ease of finding the books & 3.83 \\
\hline Laptops & 3.78 \\
\hline Copy center & 3.32 \\
\hline
\end{tabular}

Table 2 Average for each of the evaluation items. Source: Self Made

Finally, we proceeded to verify whether the ratings obtained by each of the libraries independently were statistically different between them. The averages for each of the facilities and their services can be seen in Table 3 , where it can also be seen that the overall rating was 4.00 points, which is equivalent to a satisfaction level of "satisfied".

\begin{tabular}{|l|r|r|}
\hline \multicolumn{1}{|c|}{ Library } & \multicolumn{1}{c|}{ n } & Average \\
\hline Central & 234 & 4.03 \\
\hline Nainari & 850 & 4.00 \\
\hline Navojoa & 181 & 3.90 \\
\hline Guaymas & 142 & 4.05 \\
\hline Empalme & 47 & 4.01 \\
\hline Average & 1,454 & 4.00 \\
\hline
\end{tabular}

Table 3 Participants by library and general average awarded in the evaluation

Source: Self Made
A one-factor analysis of variance (ANOVA) indicated that there is no significant influence of the variable "ascription library" (independent or qualitative variable) on the variable "general average satisfaction", (dependent or quantitative variable) with values of $\mathrm{F}(4,1449)=0.422, \mathrm{p}=.793$

The foregoing means that, although a difference of tenths or hundredths could be perceived in the marks given by students to the library that they frequent the most, these means do not differ between them statistically speaking; the level of satisfaction is not influenced or altered by which library is being evaluated, the one that the student frequents the most, in such a way that even so it could be said that the Navojoa Unit Library obtained the lowest average, this difference is not statistically significant.

\section{Conclusions and recommendations}

The educational, learning and quality evaluation are areas where an educator can perform thanks to the training received throughout their preparation, so evaluating the satisfaction of a service that is considered of vital importance for the academic life of An institution of higher education, such as library services, represents an opportunity to put into practice various knowledge and skills that will result in continuous improvement and for the benefit of the academic staff and the students that depend on it.

The first objective set out in this study was to determine the general level of user satisfaction with library services. This objective was met by obtaining a total of 1,457 responses from a total of 18,018 undergraduate, master's and doctoral students, which is equivalent to $8 \%$ of the population. It was their responses that allowed obtaining a precise numerical reading of 4.00 points on a scale from 1 to 5 , where it can be stated that users are satisfied with the services received by the ITSON library system.

The second objective was to determine the user's level of particular satisfaction with library services. This objective was achieved by being able to show the average scores obtained in each of the evaluated items, which allows the user of this report to be able to make decisions based on objective numerical evidence and not only on subjective impressions or assumptions. 
The third objective established was to determine if there is a difference in satisfaction between libraries. It was concluded that the rating given to libraries in particular does not depend on the student's affiliation, which was evidenced using the ANOVA Analysis of Variance statistical test.

To conclude, and in light of the findings, the following recommendations can be made to the library system staff: the Library administration should embark on activities that improve user satisfaction because if users are satisfied, their patronage will be assured and the economic investment made by the university will be reflected in said indicator.

One of the principles of continuous improvement indicates that evaluations should lead to improvement projects in the short term, so these numerical indicators should be used to increase satisfaction in areas that came out with a high average, but On the other hand, corrective actions must be carried out in those services whose average was the lowest on the list.

Finally, it is recommended to make these results known to the entire academic and administrative community, since they reflect the work of some, the investment of others, and the use of all. Requesting participation in a study must entail the obligation to communicate the results, their socialization, and the express commitment to improvement.

\section{References}

Aina, L. O. (2005). Library and information science text for Africa. South African Journal of Libraries and Information Science, 71(1). https://doi.org/10.7553/71-1-663

CONPAB. (2015). Diagnóstico Situacional de las Bibliotecas de las Universidades Públicas Estatales de México 1993-2013. https://conpabies.org.mx/diagnostico-desistemas-bibliotecarios/

Ekere, F. C. (2006). Administration of academic libraries: A book of readings. UCO Academic Publishers Nigeria Limited.

Emokiniovo, K. A., y Ogunrobi, S. A. (2012). Evaluating the use of faculty libraries in Nigerian universities: A case study of University of Benin. Nigerian Libraries 45(2), 1 - 7 .
Gall, M., Gall, J., y Borg, W. (2007). Educational research and introduction ( $\left.8^{\mathrm{a}} \mathrm{ed}.\right)$. Pearson.

Hernández-Sampieri, R., y Mendoza-Torres, C. P. (2018). Metodología de la investigación. Las rutas cuantitativa, cualitativa y mixta. McGrawHill.

Kerlinger, F., y Lee, H. (2002). Investigación del comportamiento. Métodos de investigación en ciencias sociales ( $4^{a}$ ed.). McGraw-Hill.

Kumar, K. (1982). Library organization. VIKAS Publishing House.

Okunu, H. O., Akalumhe, K. O., y Monu, J. O. (2011). An evaluative study of academic library services to users in Nigerian universities: A case study of Fatiu Ademola Akesode Library, Lagos State University, Ojo, Lagos. International Journal of Research in Education, 8(1), 74 80 .

Opoku, D. (2011). Improving service quality in academic library: A managerial approach. International Journal of Research in Education. 8 (2), $198-209$.

Oyewusi, F. O., y Oyeboada, S. A. (2009). An empirical study of accessibility and use of library resources by undergraduates in a Nigerian state university of technology. Library Philosophy and Practice, 277. https://digitalcommons.unl.edu/libphilprac/277

Reitz, J. (2004). Dictionary for Library and Information Science. Libraries Unlimited.

Roseroka, K. (2004). The roles of libraries. Association of African Universities. http://www.aau.org/english/documents/librole.h tm 